\title{
Developments and future potentials of anaerobic membrane bioreactors (AnMBRs)
}

\author{
Chettiyappan Visvanathan* and Amila Abeynayaka \\ Environmental Engineering and Management Program, School of Environment, Resources and \\ Development, Asian Institute of Technology, Thailand \\ (Received April 13, 2011, Revised September 01, 2011, Accepted September 15, 2011)
}

\begin{abstract}
The coupling of anaerobic biological process and membrane separation could provide excellent suspended solids removal and better biomass retention for wastewater treatment. This coupling improves the biological treatment process while allowing for the recovery of energy through biogas. This review gives a basic description of the anaerobic wastewater treatment process, summarizes the state of the art of anaerobic membrane bioreactors (AnMBRs), and describes the current research trends and needs for the development of AnMBRs. The research interest on AnMBR has grown over the conventional anaerobic processes such as upflow anaerobic sludge blanket (UASB). Studies on AnMBRs have developed different reactor configurations to enhance performances. The AnMBR performances have achieved comparable status to other high rate anaerobic reactors. AnMBR is highly suitable for application with thermophilic anaerobic process to enhance performances. Studies indicate that the applications of AnMBR are not only limited to the high strength industrial wastewater treatment, but also for the municipal wastewater treatment. In recent years, there is a significant progress in the membrane fouling studies, which is a major concern in AnMBR application.
\end{abstract}

Keywords: anaerobic membrane bioreactor; wastewater treatment; research development; membrane fouling; high rate; thermophilic process

\section{Introduction}

Membrane bioreactors (MBRs) are proving to be a promising technology for wastewater treatment because the biomass is separated from the treated water by filtration through a membrane, eliminating the operational and biological issues associated with gravity separation, and producing a suspended solid free effluent (Judd 2008, Melin et al. 2006, Visvanathan et al. 2000). The anaerobic biological treatment process consists of a series of biological reactions and involves different types of microorganisms. This complexity of requirements made the application of membrane separation with anaerobic process relatively complicated when compared with the aerobic MBR. Hence a thorough study of application of anaerobic process with membrane bioreactors is required.

The anaerobic treatment process has been applied since early the 1900s in treating excess sludge discharged from sewage treatment plants. This technology has since been developed to treat wastewaters successfully while recovering energy. Nowadays, it is considered as an established technology and it is successfully used for the treatment of many kinds of industrial wastewaters. The success of anaerobic wastewater treatment can be attributed to an efficient uncoupling of the solid retention time from the hydraulic retention time through biomass immobilization. This is usually accomplished

\footnotetext{
* Corresponding author, Professor, E-mail: visu@ait.ac.th
} 
through biofilm or granule formation. The separation of biomass from the effluent, using membrane technology, is another attractive method to retain the biomass within the anaerobic reactor.

With the global attention on reducing green house gas emissions and energy recovery form waste, the attraction on anaerobic wastewater treatment over aerobic wastewater treatment has been growing rapidly. The Copenhagen Accord (UNFCCC 2009) emphasizes the need for the reduction of green house gases (GHG) emissions in developed countries and capacity building and technology transfer to developing countries. In addition, water scarcity makes the necessity for water reuse. Hence the development of technologies which recover energy and provide suitable effluent for reuse becomes important. AnMBR is a great potential-application to achieve the two objectives, energy recovery and better quality effluent for reuse. Higher strength wastewaters where the higher organic exists; the energy content is much greater. Hence to recover maximum energy, anaerobic treatment must be applied to the high strength wastewater directly. This should increase the fraction of the potential energy recovered as biogas, and would decrease the oxygen requirement in the latter part of the treatment. Technical and economic challenges however exist; the most important being the identification of suitable anaerobic processes for each case. While being practiced for decades, interest in the reuse of anaerobically treated effluent has not much drawn attention. This is because the low carbon removal and minimum nutrient removal made it necessary for the effluent of anaerobic process to be further treated. However for some reuse applications such as effluents used for agricultural irrigation purpose where the presence of nutrients is desirable, aerobic process for further treatment can be skipped. Yet pathogen removal, biodegradation of certain compounds has to be achieved prior to the reuse applications. Membrane technology provides the separation of pathogens from effluent and complete retention of biomass allowing higher sludge retention time with effective bacterial cultures which can degrade certain types of recalcitrant constituents. There are some cases where the application of conventional anaerobic process is ineffective. If wastewaters contain particulates and/or have a high temperature, then the granule formation and biofilm processes become ineffective. Hence, under these situations, the conventional upflow anaerobic sludge blanket (UASB) and biofilm associated processes are unsuccessful. The application of the membrane technology which separates the biomass from the effluent is an excellent alternative method under these conditions.

There has been an increase in attention on AnMBR studies lately, including: reviewed studies which identified development and research directions (Liao et al. 2006), and treatment of municipal wastewater with the goal of resource recovery (Sutton et al. 2011). Even more important, studies have attempted to tackle a major challenge in the implementation of AnMBR, that is, membrane fouling. The complex biological process and the air tight reactor made observations on membrane fouling and the maintenance of a sustainable anaerobic process difficult. In light of this, recent research studies (Kim et al. 2011, Lin et al. 2010, Lin et at. 2011a, Lin et al. 2011b, Calderón et al. 2011, Huang et al. 2011) have considered membrane fouling in AnMBRs.

This review paper discus: (a) the advantages of combining membrane separation and anaerobic processes to form AnMBR; (b) the conditions which the AnMBR process provides advantages over the conventional anaerobic process; (c) existing operational and challenges; and (d) research development, and future directions.

\section{Development of AnMBR}

\subsection{Fundamentals of anaerobic wastewater treatment process}

The anaerobic biological wastewater treatment process consists of two main biochemical stages 


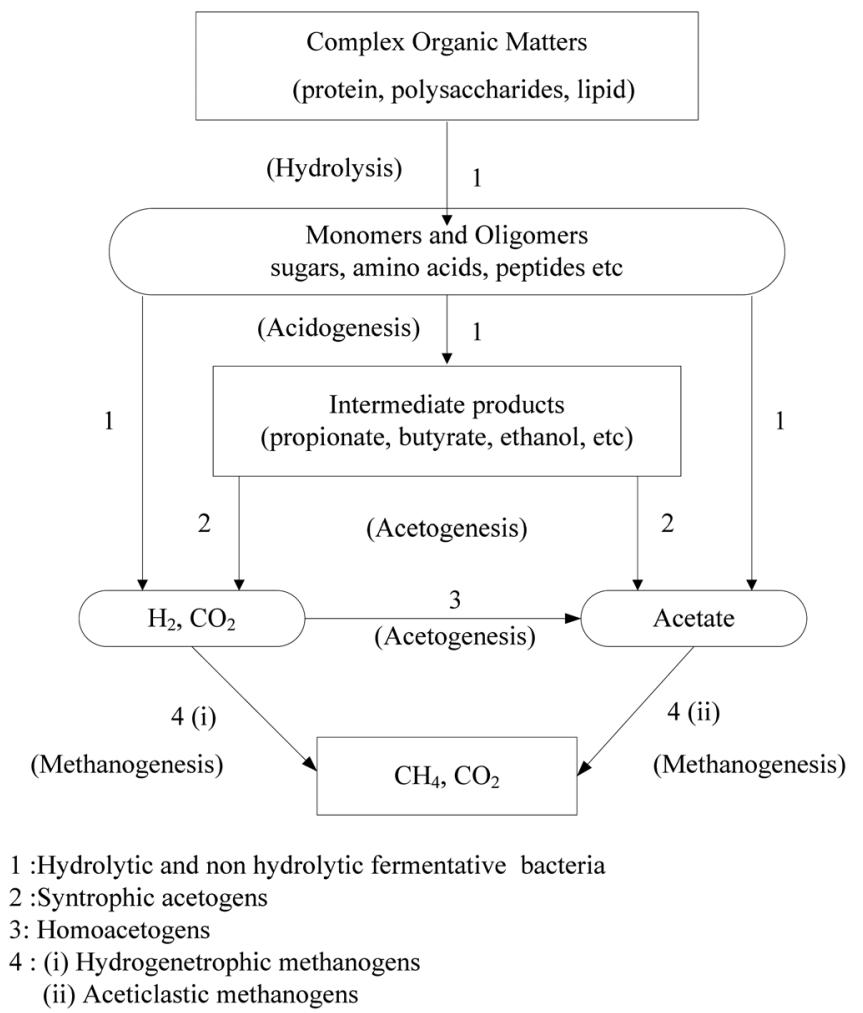

Fig. 1 Metabolic pathway of anaerobic degradation (Khanal 2008)

such as acid formation and methane formation (as illustrated in Fig. 1). In the final phase, the methanogens convert acetate, hydrogen and carbon dioxide into methane. For the methanogens the primary substrates are acetate, $\mathrm{H}_{2}$, and $\mathrm{CO}_{2}$. About $75 \%$ of methane production is from decarboxylation of acetate and the rest is from $\mathrm{CO}_{2}$ and $\mathrm{H}_{2}$ (McCarty and Smith 1986). Anaerobic symbiotic relationships amongst a variety of microbial species are an essential feature of anaerobic stabilization to keep the system balanced.

The two main rate limiting steps in anaerobic process are hydrolysis which converts complex organics into simpler derivatives and methanogenesis. The rate limiting step in the anaerobic degradation depends on the nature or the complexity of the waste that undergoes treatment. Further in the overall anaerobic treatment process hydrolysis can be the rate limiting step for wastewater which contains significant amounts of particulate matters (Henze and Haremoes 1983). As illustrated in the findings of Pavlostathis and Giraldo-Gomez (1991), the rate of hydrolysis is a function of $\mathrm{pH}$, temperature, concentration of hydrolyzing biomass, and type of particulate organic matter. In addition the hydrolysis rate in anaerobic process is increased at elevated temperatures (thermophilic range).

The anaerobic degradation of complex organics is carried out by different groups of bacteria such as fermentative acetogens, homoacetogens, hydrogenetrophic methanogens and aceticlastic methanogens. Bacteria involve in anaerobic process include Clostridium spp, Peptococcus anaerobs, Bifidobacterium spp, Desulphovibrio spp, Corynebacterium spp, Lactobacillus, Actinomyces, Staphylococcus and 
Escharichia coli. Fermentative bacteria and acetogenesis bacteria involve in the anaerobic processes are facultative, more tolerant to environmental changes and fast growers. Among those mentioned above, homoacetogens are the most concerned today (Khanal 2008) because of their ability to produce acetate which is the most important intermediate of methane production. In general, the growth rate of acetogens are considered to be high in mesophilic range (Adamse 1980) yet with specific substrates such as glucose, fructose, pyruvate, xylose, galactose and glycerate the growth rate of acetogens are optimum at thermophilic temperatures (Weigel and Oka 1981).

Methanogens are classified as archaea, strict obligate anaerobes and considered as rate limiting species in anaerobic wastewater treatment. The principal genera of methanogenic microorganisms which identified in mesophilic conditions include the rods (Methanobacterium, Methanobasillus) and spheres (Methanococcus, Methanothrix and Methanocarnia). Among these, Methanothrix and Methanocarnia are the only organisms able to use acetate to produce methane. Others produce methane using hydrogen and carbon dioxide. According to the findings of van Lier (1996) acetate utilizing bacteria exist in thermophilic reactors. However, some species of Methanocarnia are inhibited at a temperature of $65^{\circ} \mathrm{C}$. Further among hydrogen utilizing bacteria Methanobacterium could be abundant in temperatures above $60^{\circ} \mathrm{C}$.

Anaerobic microorganisms especially the methanogens are highly sensitive to environmental changes. As methanogenesis is a rate limiting reaction in anaerobic process the stability of it is directly dependent on the environmental factor such as, temperature, operating $\mathrm{pH}$, nutrients and trace elements and toxicity. Furthermore, methanogens are highly susceptible to the substrate loading variation as well.

Variation in temperature in anaerobic reactors should not exceed $0.6-1.2^{\circ} \mathrm{C}$ per day (WPCF 1987). The optimum $\mathrm{pH}$ of acetogens/acidogens are 5.5-7.2 and that of methanogens are 6.8-7.8. Operating $\mathrm{pH}$ range of methanogens is very narrow. Due to the slow growth rate of methanogens and higher rate of acetogens, acetic acid can accumulate in anaerobic reactor. This drops the reactor $\mathrm{pH}$ and inhibits methanogenesis. Therefore it is necessary to maintain reactor $\mathrm{pH}$ close to neutral for optimum methanogenic activity. This can be done by methods such as separate reactor operation and alkalinity addition. However, as demonstrated by de Gioannis (2008), anaerobic consortia are able to adapt to adverse conditions if adequate time is given.

Substances in wastewaters such as heavy metals, chlorinated hydrocarbons and cyanides as well as byproducts of microorganisms such as ammonia, sulfide and volatile fatty acids cause the toxicity of anaerobic microorganisms. In addition, inorganic nutrients such as calcium $\left(\mathrm{Ca}^{+2}\right)$ and magnesium $\left(\mathrm{Mg}^{+2}\right)$, trace elements such as cobalt $(\mathrm{Co})$ and nickel $(\mathrm{Ni})$ are also very important for the anaerobic metabolism. It is found that there is a 30 fold increase in $\mathrm{CH}_{4}$ production rate when $(\mathrm{Ni})$ and other trace elements are present (Speece et al 2006).

Anaerobic microorganisms are found to be more vulnerable to environmental changes as discussed above. Their activity is easily inhibited by several factors such as ammonia $\left(\mathrm{NH}_{3}\right)$, sulfide, light metals, heavy metals, and organic compounds including fatty acids. These inhibitory substances are often present in the feed wastewaters or in sludge. Reactor inhibition is often to be identified by decrease of steady state biogas generation and accumulation of organic acids such as propionic acid and others. In addition, presence of some compounds synergizes the inhibitory effect of other compounds. For example, the presence of sulfide ions increases inhibition of ammonia. In contrast, the presence of light metals such as $\mathrm{Na}^{+}, \mathrm{Ca}^{+2}$ or $\mathrm{Mg}^{+2}$ retards the ammonia inhibitions by antagonizing the effect over another.

Among the anaerobes, methanogens are the most vulnerable consortia over other acedogenic or 
acetogenic bacteria (Chen et al 2008). Toxicity levels of each inhibitor have reported differently in various researches and this could be attributed to the difference in reactor configurations, and seed sludge acclimatization, and the antagonistic or synergistic effect of other compounds present in feed wastewaters such as heavy metals and other ions such as $\mathrm{Ca}^{+2}, \mathrm{Mg}^{+2}, \mathrm{Na}^{+}$. Among the inhibitory compounds ammonia is more predominant in most of the cases. However, the inhibition factor largely depends on the wastewater characteristics. As an example, meat processing and dairy industry wastewaters contain high amount of protein which generate amino acids anaerobic degradation. This consequently brings about a high concentration of ammonia in the reactor. Moreover, pulp and paper industry wastewater often contain elevated amounts of sulfide concentration as well as tannins and halogenated organic carbons which causes inhibition of anaerobic process. Anaerobic reactor inhibition could be largely eliminated by the acclimatization of seed sludge to the required compound (Chen et al 2008) but the tolerable limit is depend on the acclimatized duration as well.

\subsection{Development of AnMBR studies}

In the absence of oxygen as an electron acceptor, anaerobic microbial systems discard the electrons into methane instead of using them to grow more microorganisms, leading to low biomass production. Less biomass production is an advantage due to reduced sludge treatment cost. However, the slow growth rates of the methanogenic organisms and the microbial complexity of the systems make the operation of anaerobic systems difficult. Biomass retention becomes a critical factor to keep sufficient biomass within the reactor.

Research and development efforts have been directed at retaining a high density of useful microorganisms, in order to achieve rapid and effective treatment. Technological developments in granular sludge and microbial biofilm which retain cells in the reactor have been made in order to maintain the higher biomass. For the granule sludge, UASB has proven useful, while for the biofilm process, the upflow anaerobic filter process (UAFP) and anaerobic fluidized-bed reactor (AFBR) have been developed. UASB process is capable of affording self-granulation of anaerobic microbes. Typical granule concentrations vary from to 20 to $40 \mathrm{~kg} \mathrm{VSS} / \mathrm{m}^{3}$ in the reactor. UAFP and AFBR apply the biofilm growth onto a media to immobilize biomass. Full-scale UASB, UAFP and AFBR reactors are operating at feed COD concentration ranges from 1,000 to $20,000 \mathrm{mg} / \mathrm{L}$ at hydraulic retention times (HRTs) of 0.1 to 8 days in which the COD loads are $3-14 \mathrm{~kg} / \mathrm{m}^{3}$.day. This results in a COD reduction of more than $80 \%$. Commercial high-rate anaerobic reactors are feasible because biomass is retained. When biomass is retained, the effluent suspended solids concentration is significantly lower than the biomass concentration in the reaction zone. A UASB, for example, has a biomass concentration of 20 to $40 \mathrm{~kg} \mathrm{VSS} / \mathrm{m}^{3}$ producing low suspended solids in the effluent. However, in wastewaters with particulates and/or high temperatures the granule formation and biofilm processes become ineffective. Hence, conventional UASB and biofilm associated processes are inapplicable. Similarly, the pathogen removal and achievement of effluent quality for water reuse applications is a difficult task with conventional processes. Due to limitations of conventional anaerobic process, the growing interest on AnMBR is noticeable. The trend is obviously projected on the number of publications on both processes, conventional UASB and AnMBR (Fig. 2). Starting from the early 2000s' the growth of journal publications on AnMBR has been mounting. On the other hand, studies on UASB was not grown that much.

The AnMBR process can be basically defined as a biological treatment process operated without oxygen and using a membrane to provide complete solid-liquid separation. AnMBRs were first 


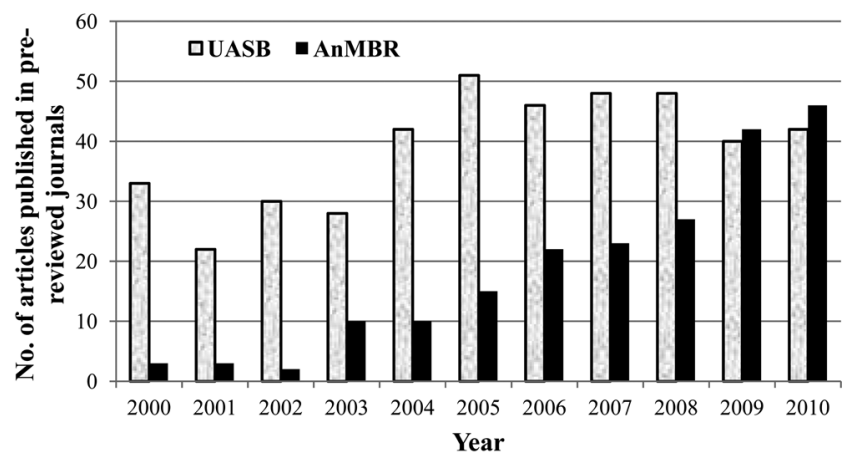

Fig. 2 Number of articles published in journals on AnMBR and UASB (Scopus 2011)

introduced in the 1980s in South Africa and till it has less investigated compared to aerobic MBR. However, today there is a growing interest in the field of AnMBR as shown in the numerous and still increasing number of studies going on. Because MBRs could operate independently in relation to the retention times, it enables to go for high organic loading rates. Therefore this became an attractive solution for low (i.e., municipal wastewater) to high strength industrial wastewater treatment with simultaneous energy recovery and less excess sludge production.

\subsection{Consideration of AnMBRs over high rate anaerobic reactors}

Anaerobic treatment could be done in low rate anaerobic reactors such as anaerobic ponds and septic tanks as well as in high rate reactors. High rate anaerobic treatment can be further classified as suspended growth and attached growth process. Anaerobic digesters, continuous stirring tank reactors (CSTRs), UASBs and AnMBRs are some examples of suspended growth process and anaerobic filters (AFs), fluidized bed reactor are some examples for high rate attached growth processes. High rate anaerobic processes have performed well in treating readily biodegradable soluble organic matters, especially carbohydrate based industrial wastewaters. High rate systems provide straightforward biogas collection facilities as compared with conventional anaerobic treatment methods such as pond systems. However, their applications in complex wastewaters such as those containing organic compounds like particulates, proteins, fats, and fibers are limited. Most of the high strength wastewater streams such as wastewaters from slaughterhouses, tanneries, and palm oil mill contains greater amounts of such compounds. These complex wastewaters are hard to degrade anaerobically since the hydrolysis of such compounds is difficult. Moreover the degradation kinetics of compounds like fats and solids are very slow and growth of granular sludge in such wastewaters is slow. In addition, the shear strength and settling velocities of the biomass is very poor under those circumstances (Fang et al. 1994a, 1994b). This causes poor performances of high rate reactors treating complex wastewaters. The organic hydrolysis rates of high rate acidogenic reactors decreases gradually (Lee et al. 2001). This is because acidogens are easily washed out from the reactor due to the poor aggregation (Kayhanian 1994). However, high rate anaerobic reactors, alone or as hybrid systems, are widely used in industrial applications. They have being operating successfully in terms of chemical oxygen demand (COD) removal and methane yield, yet the effluent quality is not good in terms of suspended solids removal. A summary of reported researches on wastewater treatment with anaerobic high rate reactors is given in Table 1. 
Table 1 Selected experimental results of anaerobic wastewater treatment performances

\begin{tabular}{|c|c|c|c|c|c|c|c|c|c|}
\hline Wastewater & $\begin{array}{l}\text { Reactor } \\
\text { Type }\end{array}$ & $\begin{array}{c}\mathrm{T} \\
\left({ }^{\circ} \mathrm{C}\right)\end{array}$ & $\begin{array}{l}\text { HRT } \\
\text { (d) }\end{array}$ & $\begin{array}{c}\text { OLR } \\
\left(\mathrm{kg} / \mathrm{m}^{3} . \mathrm{d}\right)\end{array}$ & $\begin{array}{l}\text { MLSS or } \\
\text { MLVSS }\end{array}$ & $\begin{array}{c}\mathrm{COD}_{\text {In }} \\
(\mathrm{g} / \mathrm{L})\end{array}$ & $\begin{array}{c}\text { COD } \\
\text { Removal } \\
\text { Efficiency } \\
(\%)\end{array}$ & $\begin{array}{l}\text { Methane yield } \\
\mathrm{m}^{3} \mathrm{CH}_{4} / \mathrm{kgCOD}_{\mathrm{r}}\end{array}$ & Reference \\
\hline \multirow{2}{*}{ Olive mill wastewater } & Completely-Mixed & 35 & \multirow{2}{*}{$10-40$} & \multirow{2}{*}{ - } & \multirow{2}{*}{5.5 (VSS) } & \multirow{2}{*}{52.5} & $54-92$ & $0.23-0.29$ & \multirow{2}{*}{$\begin{array}{l}\text { Borja et al. } \\
1995\end{array}$} \\
\hline & Completely-Mixed & 55 & & & & & $84-95$ & $0.29-0.37$ & \\
\hline \multirow{2}{*}{ Palm oil mill effluent } & $\begin{array}{l}\text { Two-stage UASB } \\
\text { (Acidogenic) }\end{array}$ & \multirow{2}{*}{35} & $0.9-6.5$ & & & 15.0 & \multirow{2}{*}{$>90$} & \multirow{2}{*}{$0.30-0.33$} & \multirow{2}{*}{$\begin{array}{l}\text { Borja et al. } \\
1996\end{array}$} \\
\hline & $\begin{array}{l}\text { Two-stage UASB } \\
\text { (Methanogenic) }\end{array}$ & & $0.3-14$ & $1.1-60$ & $16(\mathrm{VS})$ & NA & & & \\
\hline \multirow{2}{*}{$\begin{array}{l}\text { Cane molasses } \\
\text { alcohol stillage }\end{array}$} & Single stage CSTR & \multirow{2}{*}{55} & $36-9$ & $3.45-14.5$ & \multirow{2}{*}{-} & \multirow{2}{*}{130} & - & 0.06 & \multirow{2}{*}{ Yeoh 1997} \\
\hline & Two stage CSTR & & $5.6-33$ & $4.65-20.02$ & & & 65 as $\mathrm{COD}$ & 0.19 & \\
\hline \multirow{2}{*}{$\begin{array}{l}\text { Fruit and vegetable } \\
\text { wastes }\end{array}$} & Tubular anaerobic & 35 & 3 & \multirow{2}{*}{3.7} & \multirow{2}{*}{-} & \multirow{2}{*}{-} & \multirow{2}{*}{ - } & 0.32 & \multirow{2}{*}{$\begin{array}{l}\text { Bouallagui } \\
2004\end{array}$} \\
\hline & digester & 55 & 3 & & & & & 0.45 & \\
\hline Palm oil mill effluent & $\begin{array}{l}\text { Upflow anaerobic } \\
\text { sludge fixed film }\end{array}$ & 38 & $1.5-3$ & 2.63 to 23.15 & $42(\mathrm{VS})$ & $42-56$ & 85 & 0.35 & $\begin{array}{l}\text { Najafpour } \\
\text { et al. } 2006\end{array}$ \\
\hline Palm oil mill effluent & $\begin{array}{l}\text { Upflow anaerobic } \\
\text { sludge fixed film }\end{array}$ & 38 & $1-6$ & $0.88-34.73$ & & $5-35$ & $81-99$ & 0.35 & $\begin{array}{l}\text { Zinatizadeh } \\
\text { et al. } 2006\end{array}$ \\
\hline \multirow{2}{*}{ Potato processing } & \multirow{2}{*}{ Two Stage UASB } & 35 & \multirow{2}{*}{-} & 11 & \multirow{2}{*}{-} & \multirow{2}{*}{-} & \multirow{2}{*}{ - } & 0.41 & \multirow{2}{*}{$\begin{array}{l}\text { Parawira } \\
\text { et al. } 2007\end{array}$} \\
\hline & & 55 & & 36 & & & & 0.49 & \\
\hline $\begin{array}{l}\text { Glucose based } \\
\text { synthetic wastewater }\end{array}$ & ASBR & 35 & $1.3-5$ & $1.5-24$ & 23 (VSS) & $3.7-30$ & $86-95$ & - & $\begin{array}{l}\text { Cheong and } \\
\text { Hansen } 2008\end{array}$ \\
\hline \multirow{2}{*}{$\begin{array}{l}\text { Wastewater from } \\
\text { paper mill }\end{array}$} & \multirow{2}{*}{ Anaerobic filter } & 35 & \multirow{2}{*}{$0.3-1.0$} & $1.08-11.38$ & & 2.7 & 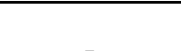 & 024032 & Yilmaz \\
\hline & & 55 & & $1.07-12.25$ & & 2.7 & - & $0.24-0.32$ & et al. 2008 \\
\hline Simulated domestic & Two stoce $\triangle$ SPP & 35 & & 0.63 & & & 69 & & Bravo \\
\hline wastewater & Iwo stage ASBRs & 35 & - & 1.22 & - & 0.5 & 50 & - & et al. 2009 \\
\hline & & & & 4.5 & & 3 & & & Ghaniyari- \\
\hline $\begin{array}{l}\text { Molasses based } \\
\text { wastewater }\end{array}$ & $\begin{array}{l}\text { Multistage biofilm } \\
\text { reactor }\end{array}$ & 35 & 0.7 & 6.75 & - & $4 . .5$ & 90 & - & Benis \\
\hline & & & & 9 & & 6 & & & et al. 2009 \\
\hline Winery wastewater & $\begin{array}{l}\text { Upflow anaerobic } \\
\text { fixed bed reactor }\end{array}$ & 35 & 0.5 & 42 & - & - & 80 & - & $\begin{array}{l}\text { Ganesh } \\
\text { et al. } 2010\end{array}$ \\
\hline
\end{tabular}

CSTR: continues stirred tank reactor, UASB: upflow anaerobic sludge blanket, ASBR: anaerobic sequencing batch reactor, MLSS: mixed liquor suspended solids, MLVSS: mixed liquor volatile suspended solids, OLR: Organic loading rate, CODIn Influent COD 
Several studies have conducted on the treatment of palm oil mill effluents. Palm oil mill effluent is an industrial wastewater which has very high COD and a low $\mathrm{pH}$. This wastewater contributes to environmental degradation largely because the wide use of conventional treatment pond system for palm oil mill effluent treatment. Among the reported studies with hybrid anaerobic high rate reactors such as Zinatizadeh et al. (2006), Najafpour et al. (2006), and Borja et al. (1996) have obtained COD removal efficiency of more than $85 \%$ and methane yield of 0.30 to $0.35 \mathrm{~m}^{3} \mathrm{CH}_{4} / \mathrm{kg}$ $\mathrm{COD}_{\mathrm{R}}$. Even though studies have been conducted in hybrid systems, they were not able to decouple the HRT and the solid retention time (SRT). In such cases, a higher HRT is required, especially for biodegradation of complex wastewaters. The effect of HRT in an anaerobic bioreactor was explained by Zinatizadeh et al. (2006), where the reduction of HRT leads to the accumulation of volatile fatty acids (VFAs) in the reactor while reducing the COD removal efficiency and methane yield. This effect has been higher at high loading rates and high influent COD levels. Further this observation has explained due to the unbalance between acid formation and methane generation in anaerobic process operates in higher organic loading rate at low HRT.

The findings of Yeoh (1997) indicate three times more methane yield in two-stage CSTR than the single stage reactor for sugar cane molasses stillage treatment. However, the COD removal efficiency of the two-stage system is only $65 \%$ while the five day biochemical oxygen demand $\left(\mathrm{BOD}_{5}\right)$ removal is about $85 \%$. This difference in $\mathrm{COD}$ and $\mathrm{BOD}_{5}$ removal could be due to the composition of molasses such as melanoidine pigments which are hardly biodegradable but contribute to COD largely. It should be noted that $\mathrm{COD}$ and $\mathrm{BOD}_{5}$ removal efficiencies of hydrolytic reactor are less than $8 \%$, but the methanogenic reactor has exhibited improved removal efficiency. Further findings Yeoh (1997) illustrates that two-stage anaerobic system can tolerate higher loading rates without affecting the removal efficiency over that of single stage system.

Reactors operated at thermophilic temperatures have given higher methane yields (Yeoh 1997, Borja et al 1995, Bouallagui 2004, Parawira et al 2007). Moreover, the thermophilic process exhibits some other advantages such as higher metabolic rates, effective removal of pathogenic microorganisms, and the elimination of cooling needs when wastewater is discharged at high temperature (Jeison et al. 2009a). The effect of temperature is particularly important for the hydrolysis process. The hydrolysis rate of cellulose in thermophilic conditions is around 5-6 times higher than the value observed in mesophilic conditions (Bouallagui et al. 2004).

\subsection{Different types of AnMBRs}

The membrane may be operated under pressure or it may be operated under a vacuum. In the first approach, the membrane is separated from the bioreactor and a pump is required to push the bioreactor effluent into the membrane unit which makes permeate to come through the membrane. This configuration is often called as an external cross-flow membrane bioreactor (Fig. 3(a)). The cross-flow velocity of the liquid across the surface of the membrane serves as the principle mechanism to disrupt cake formation on the membrane. When the membrane is immersed into the bioreactor and operated under a vacuum (Fig. 3(b)), instead of under direct pressure, the configuration is called submerged membrane bioreactor due to the location of the membrane. In this configuration, a pump or gravity flow due to elevation difference is used to withdraw permeate through the membrane. Because the velocity of the liquid across the membrane cannot be controlled, cake formation can be disrupted by vigorously bubbling gas across the membrane surface. For aerobic MBRs, the air used also provides aeration, while for AnMBRs biogas must be used. The vacuum- 


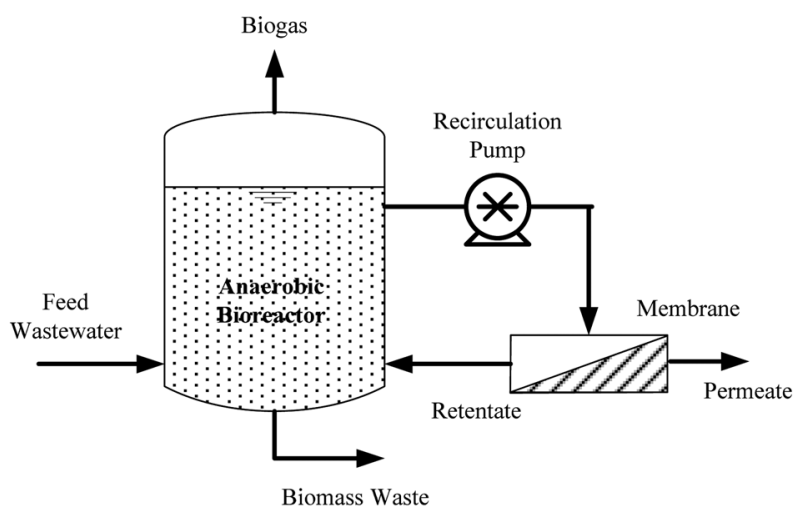

(a) External cross-flow

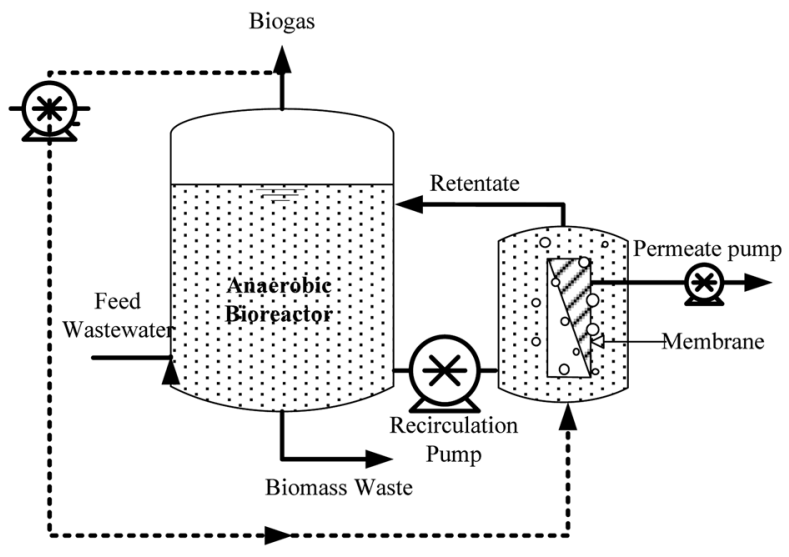

(c) External gas-lift

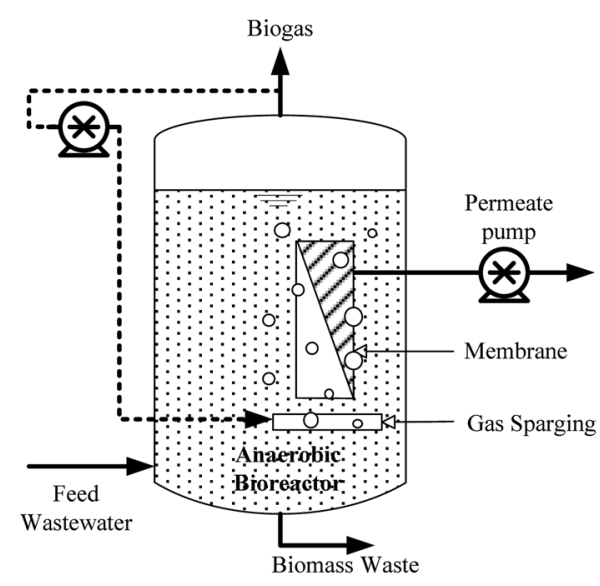

(b) Submerged

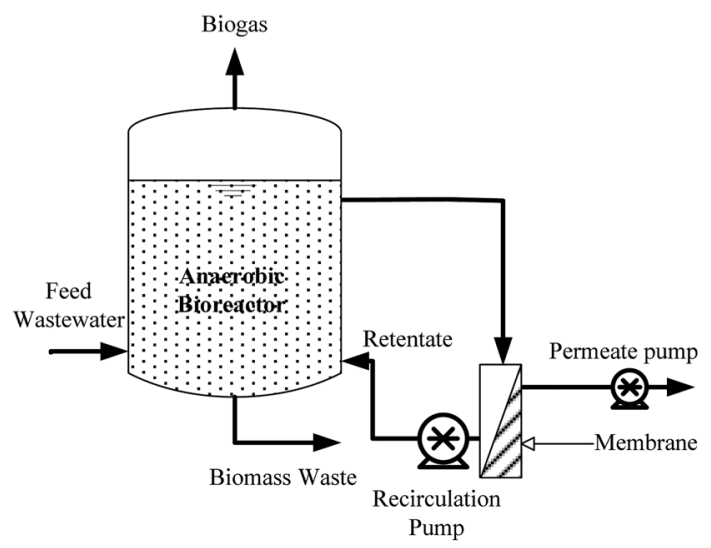

(d) External semi dead-end

Fig. 3 Different configurations of AnMBRs

driven immersed membrane approach may be used in two configurations. The applications of submerged MBRs for anaerobic wastewater treatment are still limited. The observation, investigation and maintenance difficulties of membranes inside a closed anaerobic reactor made the external membrane operation favorable. Membrane fouling in AnMBRs, which is still under the research and development stage, is another driving force on the studies of different configurations of AnMBRs. Recently some submerged AnMBR application studies were reported (Lin et al. 2010, Lin et al. 2011a, Lin et al. 2011b). To reduce cake formation on the membranes in submerged AnMBRs, the produced biogas is recirculated and used instead of air bubbling in aerobic submerged MBRs (Lin et al. 2010, Lin et al. 2011a, Lin et al. 2011b).

The membrane may be immersed directly into the bioreactor or immersed in a separate chamber (Fig. 3(c)). The latter configuration now looks like an external membrane, and will likely require a pump to return the retentate to the bioreactor. However, unlike the external cross-flow membrane, the membrane here is operated under a vacuum instead of under pressure. The external chamber configuration is used for full-scale aerobic wastewater treatment plants because it provides for easier 


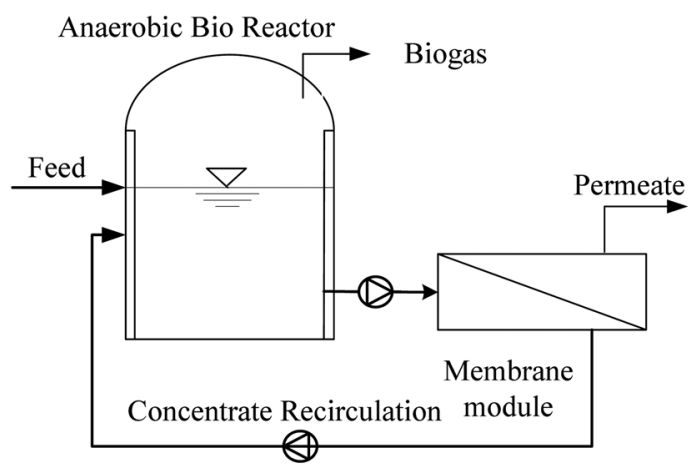

(a) Single stage

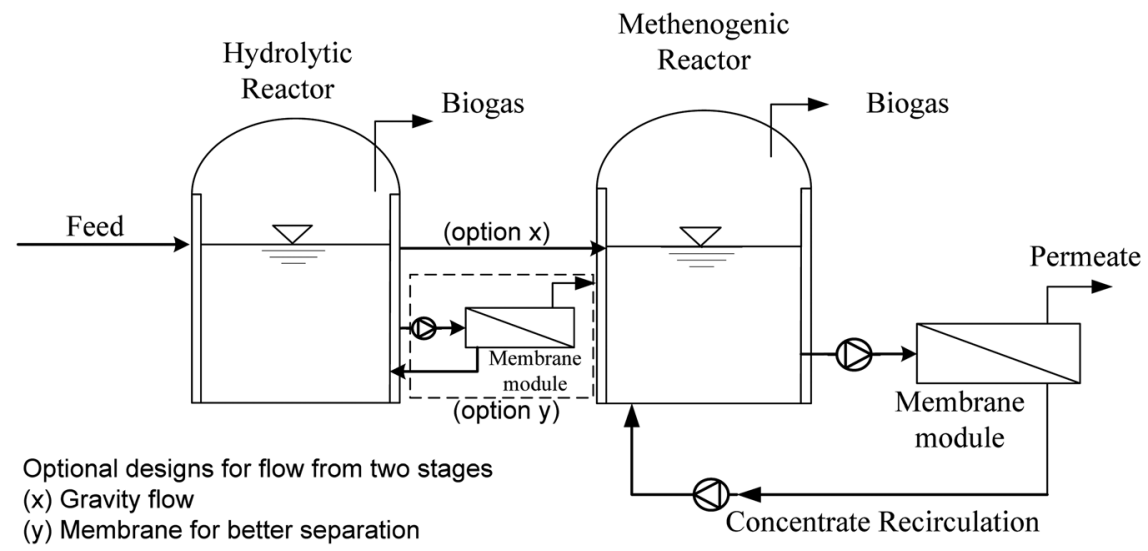

(b) Two stage

Fig. 4 Single and two stage AnMBR configurations

cleaning of the fouled membranes, because the chambers can be isolated instead of the membranes being physically removed. More studies are conducted in order to enhance the performance of AnMBR. I.e., the configuration (d) in Fig. 3, the system is operating intermittently under semi deadend mode to reduce the continuous pumping cost and to minimize the harmful effects, such as biomass activity reduction, of sludge pumping (Wijekoon et al. 2011).

Another AnMBR reactor configuration is the two-stage reactor configuration. In two-stage reactor configuration the reactions of hydrolysis, acetogenesis and acidogenesis occur within the first reactor which is named as the hydrolytic (or acidogenic) reactor, followed by methanogenic reactor where the methanogenic process take place (Fig. 4). The methanogenic reactor which facilitates for the methanogens operates in a strictly defined optimum $\mathrm{pH}$ range for the growth of the microorganisms. In a single-stage reactor, where both of the processes take place inside, the maintenance of optimum conditions for the acid formation and methane formation is impossible. The biological reactions of the different species in a single stage reactor can be in direct competition with each other. In a twostage treatment system two reactors are operating with the optimized conditions of the respective bacteria to bring maximum control of the bacterial communities living in the reactor. 
Acidogenic bacteria produce organic acids. They grow fast with higher biomass yield than methanogens. In addition methanogenic bacteria require stable $\mathrm{pH}$ and temperatures in order to optimize their performance. In the past, operation of two-stage anaerobic system was hindered by difficulties in solid-liquid separation and the maintenance of separate and distinct biomass populations in each reactor (Anderson et al.1986). Yet the membrane coupled bioreactors provides the applicability of the two-stage anaerobic degradation both with excellent separation and high biomass retention.

\section{Performances of AnMBRs}

It is obvious that anaerobic wastewater treatment is especially suitable for high strength wastewaters and could operate in higher loading rates. Furthermore, with the advantages of biomass retention, membrane coupled anaerobic membrane bioreactors are able to operate at higher loadings conditions. In addition, considering the excellent biomass retention of membrane process, application of thermophilic conditions and particulate wastewater conditions, it is expected that, its performances are successful. A summary of performances of reported studies on AnMBR is listed in Table 2.

AnMBRs have operated in wide range in terms of different feed concentrations, loading rates, reactor types in mesophilic as well as in thermophilic conditions. Most AnMBRs studies conducted in CSTR configuration with pressure driven mode reactors have achieved good COD removal efficiencies (Bailey et al. 1994, Fakhru'l-Razi 1994, Saddoud et al. 2007). In addition to that Lew et al. (2009) have studied on external configuration under gravity flow instead of having pressure pump and have achieved $88 \%$ of COD removal for domestic wastewater. This could opens new research directions in order to achieve high biomass activity and less fouling in external cross flow AnMBR applications. Early stage, high rate AnMBR studies were conducted under external membrane configuration reactors (Bailey et al. 1994, Jeison and Lier 2006, Jeison et al. 2009a, Yejian et al. 2008). Successful performances of CSTR applications would lead to the simple reactor construction and easy maintenance and operation over the complex high rate reactors in the wastewater treatment sector.

Most of the studies worked with synthetic wastewaters at the initial stage due to the easiness in process control. The feed solutions used in these studies were: VFA, sucrose, glucose, simulated domestic wastewater, as well as simulated high salinity wastewaters. Among those studies, almost all the studies have achieved good removal efficiencies such as more than 90\%. Jeison et al. (2008) has compared UASB and membrane coupled UASB to treat mixture of VFA with high salinity content similar to the salinity of sea water. Authors have observed excellent performances with membrane coupled UASB (AnMBR) over the UASB alone. Better performance with membrane coupling in this study is attributed to higher biomass activity due to high biomass retention capacity of the AnMBR whereas washout of biomass under extreme condition has caused the failure of the UASB system alone.

The use of industrial or other types of high strength real wastewater was also studied and achieved very good removal efficiencies as well. For an example, Saddoud et al. (2007) studied with cheese whey effluent with influent COD in the range of $12-80 \mathrm{~kg} / \mathrm{m}^{3}$ and COD loading of $3-20 \mathrm{~kg} \mathrm{COD} / \mathrm{m}^{3} . \mathrm{d}$. Interestingly, the study was able to achieve $98.5 \%$ of COD removal efficiency. Cheese whey contains high levels of fats which make difficulties in anaerobic high rate reactors due to biomass wash out and less activity by making a coat over the biomass. However, this performed well in terms of COD removal and biogas yield $\left(0.38 \mathrm{~m}^{3} \mathrm{CH}_{4} / \mathrm{kg}\right.$ COD $)$ with the two stage CSTRs. Most of 
Table 2 Selected experimental details of AnMBRs for wastewater treatment

\begin{tabular}{|c|c|c|c|c|c|c|c|c|c|c|}
\hline "Wastewater & $\begin{array}{c}\text { Reactor } \\
\text { Type }\end{array}$ & $\begin{array}{c}\mathrm{T} \\
\left({ }^{\circ} \mathrm{C}\right)\end{array}$ & $\begin{array}{c}\mathrm{HRT} \\
\text { (h) }\end{array}$ & $\begin{array}{c}\text { Flux } \\
\left(\mathrm{L} / \mathrm{m}^{2} . \mathrm{h}\right)\end{array}$ & $\begin{array}{c}\text { OLR } \\
\left(\mathrm{kg} / \mathrm{m}^{3} . \mathrm{d}\right)\end{array}$ & $\begin{array}{l}\text { MLSS } \\
\left(\mathrm{kg} / \mathrm{m}^{3}\right)\end{array}$ & $\begin{array}{l}\mathrm{COD}_{\text {In }} \\
\left(\mathrm{kg} / \mathrm{m}^{3}\right)\end{array}$ & $\begin{array}{c}\text { Efficiency } \\
(\%)\end{array}$ & $\begin{array}{c}\text { Membrane Operating } \\
\text { Configuration }\end{array}$ & Reference \\
\hline Synthetic & UASB & 30 & 14.4 & 20 & 8.3 & - & 5 & 99 & External Cross Flow & $\begin{array}{l}\text { Bailey et al. } \\
1994\end{array}$ \\
\hline Industrial & - & 35 & 92 & - & 20 & $31-38$ & $46-84$ & $98-96$ & External Cross Flow & $\begin{array}{l}\text { Fakhru'l-Razi } \\
1994\end{array}$ \\
\hline $\begin{array}{l}\text { Particulate synthetic } \\
\text { wastewater }\end{array}$ & CSTR & 35 & $120,80,48$ & - & $1,1.5,2.5$ & 15 & 5 & 98 & $\begin{array}{l}\text { External Cross Flow } \\
\text { Polysulfone flat plate, } \\
\text { UF }\end{array}$ & $\begin{array}{l}\text { Harada et al. } \\
1994\end{array}$ \\
\hline $\begin{array}{l}\text { Alcohol distillery } \\
\text { wastewater }\end{array}$ & CSTR & $53-55$ & 360 & 10 & $<2$ & 3 & 223 & 97 & Submerged, UF & $\begin{array}{l}\text { Choo and Lee } \\
1996\end{array}$ \\
\hline $\begin{array}{l}\text { Potato stached } \\
\text { bleaching wastewater }\end{array}$ & CSTR & - & - & - & $>6$ & $>15$ & 33 & - & $\begin{array}{l}\text { MF, Tubular, } \\
\text { Gas sparging }\end{array}$ & $\begin{array}{l}\text { Brockmann } \\
\text { and } \\
\text { Seyfried } 1996\end{array}$ \\
\hline $\begin{array}{l}\text { Pretreated alcohol } \\
\text { distillery }\end{array}$ & CSTR & 55 & 250 & - & $3-3.5$ & 2 & 40 & $>90$ & $\begin{array}{l}\text { External cross } \\
\text { flow }(3 \mathrm{~m} / \mathrm{s}) \\
\text { 1. Polypropylene } \\
\text { (hydrophobic) }(14 \mu \mathrm{m}) \\
\text { 2. Zinkonia skinned } \\
\text { inorganic }(0.14 \mu \mathrm{m})\end{array}$ & $\begin{array}{l}\text { Kang et al. } \\
2002\end{array}$ \\
\hline $\begin{array}{l}\text { Food wastewater } \\
\text { (Flour processing) }\end{array}$ & - & 37 & $>2$ & - & 4.5 & - & 15 & 90 & $\begin{array}{l}\text { External cross flow, } \\
\text { flat sheet. } \\
\text { Polyethersulphone } \\
\text { UF. MWCO 20-70 kDa }\end{array}$ & He et al. 2005 \\
\hline $\begin{array}{l}\text { Acetate and ethanol } \\
\text { based synthetic } \\
\text { wastewater }\end{array}$ & - & 33 & 24 & 4.7 & 14 & - & $1-5.9$ & 80 & $\begin{array}{l}\text { Submerged, mean pore } \\
\text { size of } 0.2 \mu \mathrm{m}\end{array}$ & $\begin{array}{l}\text { Vallero et al. } \\
2005\end{array}$ \\
\hline Synthetic & CSTR & $54-56$ & 70 & - & 4 & $1.3-1.9$ & 17 & $78-84$ & Cross flow & Lee et al. 2006 \\
\hline \multirow{2}{*}{$\begin{array}{l}\text { Synthetic } \\
\text { wastewater (VFA) }\end{array}$} & UASB & 30 & 8 & 21 & 15 & \multirow{2}{*}{$25-50$} & \multirow[b]{2}{*}{5} & & \multirow{2}{*}{$\begin{array}{l}\text { gas-sparged submerged } \\
\text { (Tubular polysulphone, } \\
\text { MF, pore size } 0.2 \mu \mathrm{m} \text { ) }\end{array}$} & \multirow{2}{*}{$\begin{array}{l}\text { Jeison and Lier } \\
2006\end{array}$} \\
\hline & CSTR & 55 & 6 & $16-23$ & 20 & & & & & \\
\hline
\end{tabular}


Table 2 Continued

\begin{tabular}{|c|c|c|c|c|c|c|c|c|c|c|}
\hline Wastewater & $\begin{array}{l}\text { Reactor } \\
\text { Type }\end{array}$ & $\begin{array}{c}\mathrm{T} \\
\left({ }^{\circ} \mathrm{C}\right)\end{array}$ & $\begin{array}{l}\text { HRT } \\
\text { (h) }\end{array}$ & $\begin{array}{c}\text { Flux } \\
\left(\mathrm{L} / \mathrm{m}^{2} \cdot \mathrm{h}\right)\end{array}$ & $\begin{array}{c}\text { OLR } \\
\left(\mathrm{kg} / \mathrm{m}^{3} . \mathrm{d}\right)\end{array}$ & $\begin{array}{l}\text { MLSS } \\
\left(\mathrm{kg} / \mathrm{m}^{3}\right)\end{array}$ & $\begin{array}{l}\mathrm{COD}_{\text {In }} \\
\left(\mathrm{kg} / \mathrm{m}^{3}\right)\end{array}$ & $\begin{array}{l}\text { Efficiency } \\
(\%)\end{array}$ & $\begin{array}{l}\text { Membrane Operating } \\
\text { Configuration }\end{array}$ & Reference \\
\hline $\begin{array}{l}\text { Synthetic } \\
\text { wastewater (VFA) }\end{array}$ & - & 55 & - & 15 & 50 & 35 & $10-100$ & $\begin{array}{c}98 \\
\text { (as VFA } \\
\text { removal) }\end{array}$ & $\begin{array}{l}\text { Submerged. Gas lift } \\
\text { (biogas sparging), } \\
\text { Tubular polysulphone } \\
\text { MF }\end{array}$ & $\begin{array}{l}\text { Jeison and Lier } \\
2007\end{array}$ \\
\hline \multirow{2}{*}{ Cheese Whey } & \multirow{2}{*}{$\begin{array}{l}\text { Two } \\
\text { stage } \\
\text { CSTR }\end{array}$} & 37 & 24 & - & 2.86 & - & 70 & 98.5 & \multirow{2}{*}{$\begin{array}{l}\text { External microfiltration } \\
\text { (Cross flow). Ceramic } \\
\text { membrane, } 0.2 \mu \mathrm{m}\end{array}$} & \multirow{2}{*}{$\begin{array}{l}\text { Saddoud et al. } \\
2007\end{array}$} \\
\hline & & 37 & 96 & - & $3-19.78$ & 6.4 & $12-80$ & - & & \\
\hline \multirow{2}{*}{$\begin{array}{l}\text { Synthetic } \\
\text { wastewater (VFA) }\end{array}$} & \multirow{2}{*}{-} & \multirow{2}{*}{55} & \multirow{2}{*}{-} & 7 & \multirow{2}{*}{ - } & 35 & \multirow{2}{*}{-} & \multirow{2}{*}{-} & Submerged & \multirow{2}{*}{$\begin{array}{l}\text { Jeison and Lier } \\
2008\end{array}$} \\
\hline & & & & 28 & & 20 & & & Cross flow & \\
\hline $\begin{array}{l}\text { Sucrose, peptone } \\
\text { and meat extract } \\
\text { based synthetic } \\
\text { wastewater }\end{array}$ & CSTR & - & 6 & 9 & 16 & - & 4 & 98 & $\begin{array}{l}\text { Submerged } 0.4 \mu \mathrm{m} \text { pore } \\
\text { size, polyethylene }\end{array}$ & $\begin{array}{l}\text { Akram and } \\
\text { Stuckey, 2008a }\end{array}$ \\
\hline $\begin{array}{l}\text { Synthetic } \\
\text { wastewater (VFA) } \\
\text { with high salinity }\end{array}$ & $\begin{array}{l}\text { UASB \& } \\
\text { CSTR }\end{array}$ & 30 & - & 15 & - & 30 & $10-11$ & - & $\begin{array}{l}\text { External (microfiltration } \\
\text { tubular membrane, } \\
0.2 \mu \mathrm{m}\end{array}$ & $\begin{array}{l}\text { Jeison et al. } \\
2009 \mathrm{~b}\end{array}$ \\
\hline \multirow{3}{*}{$\begin{array}{l}\text { Synthetic } \\
\text { wastewater (VFA) }\end{array}$} & \multirow{3}{*}{ CSTR } & 55 & - & 35 & - & 7.2 & - & - & $\begin{array}{l}\text { Submerged (Dead end, } \\
\text { Nonwoven membrane) }\end{array}$ & \multirow{3}{*}{$\begin{array}{l}\text { Jeison et al. } \\
2008\end{array}$} \\
\hline & & \multirow{2}{*}{30} & \multirow{2}{*}{-} & \multirow{2}{*}{$0.5-3$} & \multirow{2}{*}{ - } & 17.5 & & & Submerged (Dead end) & \\
\hline & & & & & & 25.6 & & & External (Dead end) & \\
\hline $\begin{array}{l}\text { Thermo-mechanical } \\
\text { pulping whitewater }\end{array}$ & CSTR & 37 & - & $4.8-9.1$ & $2.6-4.8$ & $6.7-11.3$ & - & 90 & $\begin{array}{l}\text { Submerged (Biogas } \\
\text { sparging } 0.75 \mathrm{~L} / \mathrm{min} \text { ) }\end{array}$ & $\begin{array}{l}\text { Lin et al. } \\
2011 \mathrm{~b}\end{array}$ \\
\hline $\begin{array}{l}\text { Molasses based } \\
\text { synthetic wastewater }\end{array}$ & $\begin{array}{l}\text { Two } \\
\text { stage } \\
\text { reactors }\end{array}$ & 55 & 24 & - & $5-8$ & $3-8$ & $10-15$ & $70-83$ & $\begin{array}{l}\text { External semi dead-end } \\
(0.1 \mu \mathrm{m})\end{array}$ & $\begin{array}{l}\text { Wijekoon et al. } \\
2011\end{array}$ \\
\hline
\end{tabular}

CSTR: continues stirred tank reactor, UASB: upflow anaerobic sludge blanket, ASBR: anaerobic sequencing batch reactor, MLSS: mixed liquor suspended solids, MLVSS: mixed liquor volatile suspended solids, OLR: Organic loading rate, CODIn : Influent COD 
the reported studies are conducted in mesophilic range. However, thermophilic anaerobic treatment is one of the areas that have higher potential of AnMBR application and it urges more researches to optimize the performances. In addition, studies of Jeison and Lier (2006) provided a comparison on AnMBR operation in thermophilic and mesophilic conditions, clearly indicating the ability of achieving high OLRs with smaller HRT in thermophilic AnMBR.

Studies on AnMBR conducted with low to medium strength wastewater have generally achieved more than 90\% removal efficiencies (Table 2). Brockmann and Seyfried, (1996) have illustrated the disadvantage of cross flow operation associated with biomass activity reduction in AnMBR. Further, the authors recommended the recirculation velocity in cross flow would not exceed $5 \mathrm{~m} / \mathrm{s}$ to minimize the biomass activity reduction. In addition, most of the studies have used biogas bubbling as a fouling reduction strategy, achieved successful performances (Stuckey and Trzcinski 2008, Jeison and Lier 2007). Furthermore, OLRs achieved so far were not very high yet the study of Fakhru'lRazi (1994) has achieved a high OLR $\left(20 \mathrm{~kg} / \mathrm{m}^{3} . d\right)$ for high strength wastewater $\left(46-84 \mathrm{~kg} / \mathrm{m}^{3}\right)$, obtaining about 98\% COD removal for industrial wastewater under mesophilic conditions. In addition, Jeison and Lier (2007) achieved a similar range of OLR but for medium concentration wastewater while Choo and Lee (1996) obtained about 84\% COD removal efficiency with high strength wastewater with low OLR. In addition Akram and Stukey, (2008a) have achieved 98\% of COD removal for OLR of $16 \mathrm{~kg} / \mathrm{m}^{3}$.d. Interestingly the HRT of this study was only $6 \mathrm{~h}$. Further, the authors mentioned during acclamation with same feed only $90 \%$ of COD removal was achieved (Akram and Stukey 2008b). Addition of powdered activated carbon (PAC) has improved the removal efficiency, improved the permeate flux.

Methane yield is an important parameter which reflects the performances of the anaerobic wastewater treatment systems. Since the studies on AnMBR are still under development phase, the studies on biogas yield optimization have not gained much attention. However the studies which

Table 3 Performances of aerobic MBR and AnMBR treating high-strength wastewater with similar properties

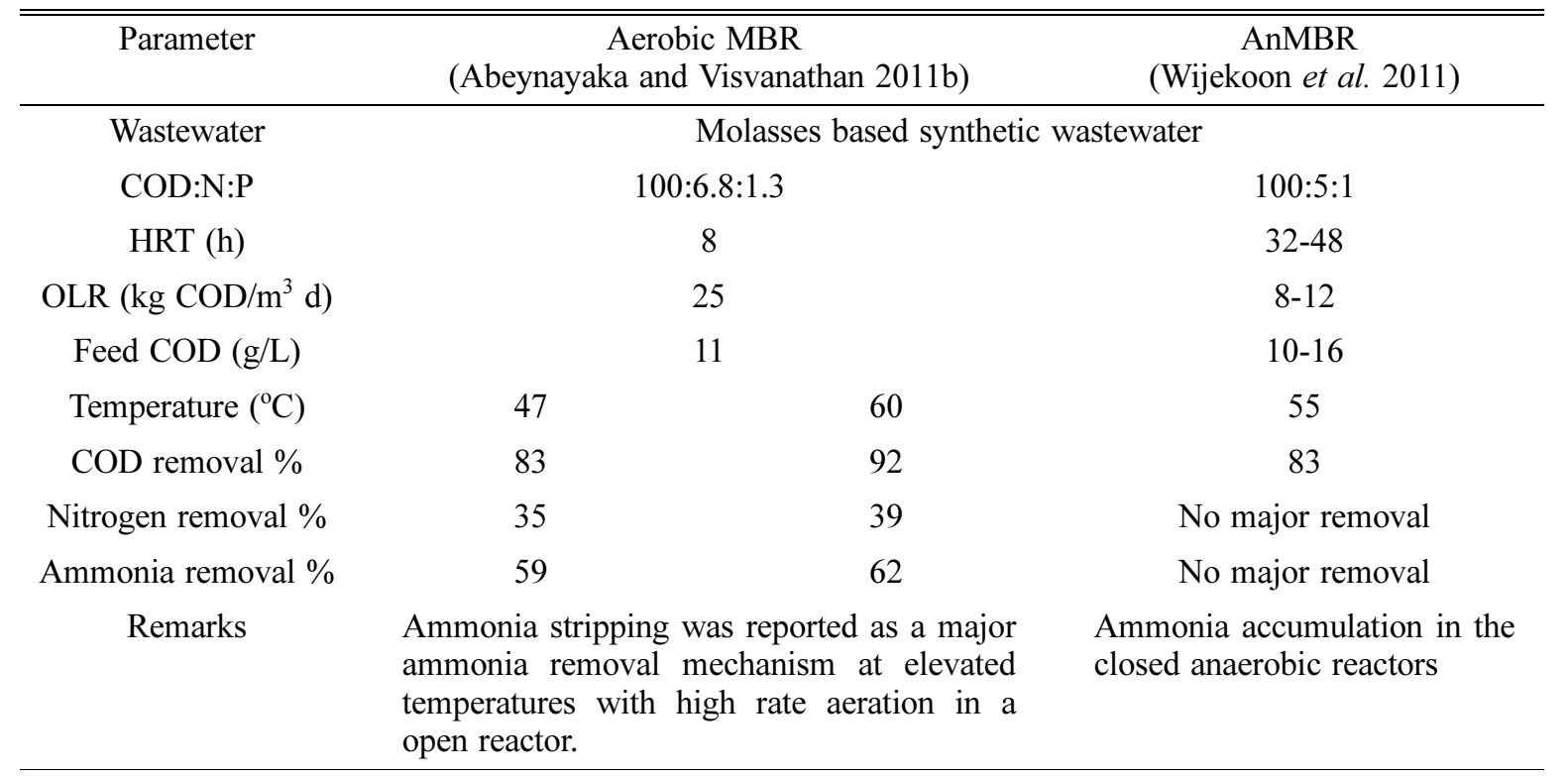


reported the methane yields indicate around $0.27-0.36 \mathrm{~m}^{3} \mathrm{CH}_{4} / \mathrm{kg} \mathrm{COD}$ (Lin et al. 2011a, Wijekoon et al. 2011, Fakhru'l-Razi 1994) which his inline with other high rate anaerobic reactors (indicated in Table 1).

While high rate anaerobic treatment process (Tables 1,2) including AnMBRs have achieved considerable improvements, compared to the initial stages of the anaerobic process, still the process has not been reached the higher rates of aerobic process (Abeynayaka and Visvanathan 2011a). Under similar types of wastewater the AnMBRs requires several times larger retention time and accommodates lower loading rates compared to aerobic MBRs (Wijekoon et al. 2011, Abeynayaka and Visvanathan 2011b). Table 3 indicates a comparison of two MBRs under aerobic and anaerobic conditions. Under aerobic conditions notably higher OLRs can be achieved. Interestingly the ammonia removal at elevated temperatures in aerobic MBR is higher due to stripping from the open reactor with high aeration rtes. However, a similar type of ammonia removal processes were not displayed with AnMBR due to closed reactor conditions.

\section{Future prospects and research directions}

For the easiness of identifying the possible applications of AnMBRs for wastewater treatment, the wastewaters can be characterized based on two aspects, namely, its concentration and its particulate nature (nature of constituent). According to that wastewater can classified in to four categories namely (a) high strength low particulate (b) high strength high particulate (c) low strength high particulate and (d) low strength low particulate wastewater (Fig. 5). Among the four, the high strength soluble wastewaters are currently treating well in high rate anaerobic sludge retaining reactors such as UASB. Therefore, AnMBR application in this type of wastewater is attractive only if higher suspended solids removal is required in applications such as wastewater reuse purposes. However, there will be a need to compensate some energy produced from biogas, which reduces the net energy gain of AnMBR over conventional processes (i.e., UASB). Yet, wastewaters with high particulate concentration urge higher SRT as well as a compact system with higher biomass concentration for the complete hydrolysis of slowly degrading particulates. The growth and

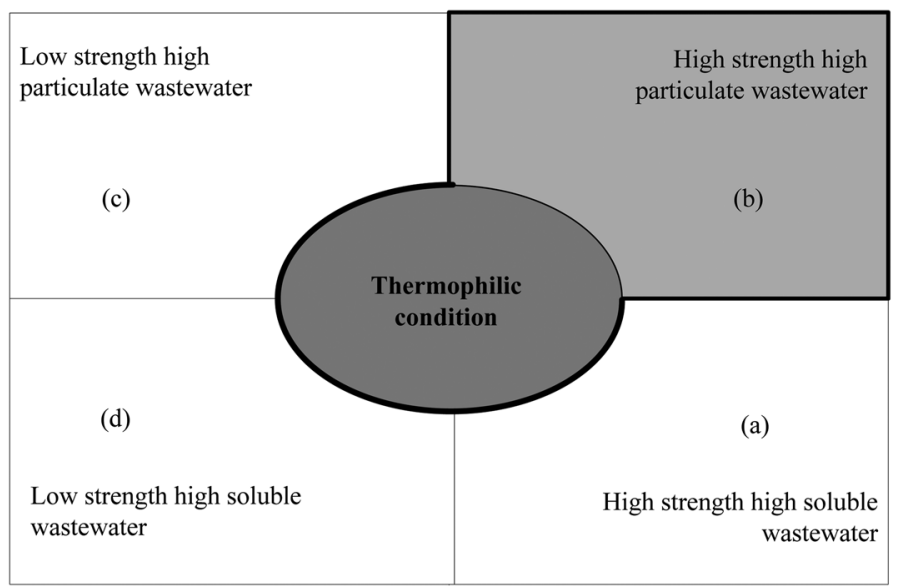

Fig. 5 Application of AnMBRs to different types of wastewater (modified from Liao et al. 2006) 
accumulation of granular sludge, in such waste streams is very slow (Fang et al. 1994a). Design specifications normally require that operating levels of fat concentrations to be in lower range as $150-300 \mathrm{mg} / \mathrm{L}$ (as oil and grease), while levels in animal processing waste streams can reach the range of $1000-1500 \mathrm{mg} / \mathrm{L}$ (Batstone et al. 2000). This causes poor performances of high rate conventional reactors treating particulate wastewaters.

AnMBRs provide an excellent environment for the degradation of wastewaters with particulate matter. Therefore, there is an extensive opportunity to use AnMBR in treatment of effluents from distillery, brewery, potato starch, slaughterhouses, pulp and paper, palm oil mill, tanneries, gelatin manicuring industries as well as for the treatment of sludge from wastewater treatment plants. In addition, application of AnMBR in high strength wastewater with high salinity and toxicity is also highly favorable (Jeison et al. 2008). While extreme conditions usually cause system failure due to lack of biomass wherein they wash out even in high rate anaerobic reactors, an AnMBR will be able to facilitate this due to its ability to retain biomass and its ability to adapt to the extreme conditions.

The instability of attached growth and granule process at thermophilic anaerobic conditions insists the application of membrane process irrespective to the wastewater conditions. As described in previous sections the enhanced methane yield and biodegradability of the thermophilic anaerobic process favors the operation of anaerobic wastewater treatment at reactors at elevated temperatures. Apart from that the treatment of high temperature effluent without cooling is possible with thermophilic AnMBRs. Hence the shaded area of the Fig. 5 has high potential of application AnMBRs for wastewater treatment. Recent studies on coupling of membrane distillation with biological wastewater treatment (Teoh et al. 2011) indicate research possibility on membrane distillation anaerobic bioreactor. Probably this would be an interesting approach due to excellent treated water quality and fairly low pressure operation saving energy demand.

There is also a great opportunity of applying AnMBR for low strength wastewaters with higher particulate concentration or low strength wastewaters that completely soluble with respect to sludge retention. Energy recovery and reuse of treated effluent are major considerations of interests of AnMBR in low strength wastewater treatment. The energy recovery from low strength wastewaters seem to be fairly low due to low organic content. Yet the study of Shizas and Bagley (2004) shows that the potential energy in the organic content of municipal wastewater to be up to nine times greater than the electricity needed to operate a municipal wastewater treatment plant. Similarly, the reuse options of treated effluent are another eye opening interests. The recent trends of research publications are a good indicator of the applications of AnMBR in both high strength and low strength wastewaters. It indicates a huge increment of AnMBR studies in industrial high strength wastewater treatment (Fig. 6). At the same time, the number of studies on municipal wastewater has also increased in considerable numbers. For low strength wastewaters, the opportunities of reuse are higher. Application of anaerobic processes leads to low nutrient removal, hence the effluent consists of higher amounts of nitrogen and phosphorous. This opens opportunities for recovering nutrients from wastewater. The reuse applications such as agriculture and horticulture, where the presence of nutrient is an advantage, have vast potentials in places where the water is limited. However, the removal of pathogens plays an important role in such reuse applications. Protozoa (i.e Cryptosporidium and Giardia) cysts and helminthes eggs which are larger in size and persistent for conventional disinfection processes are easily eliminated by membrane separation. Recent studies of Ho and Sung (2009) indicate that AnMBR treating municipal wastewater with COD around $500 \mathrm{mg} / \mathrm{L}$ could recover methane up to $48 \%$ while the effluent COD was found bellow $40 \mathrm{mg} / \mathrm{L}$. Hence, the 


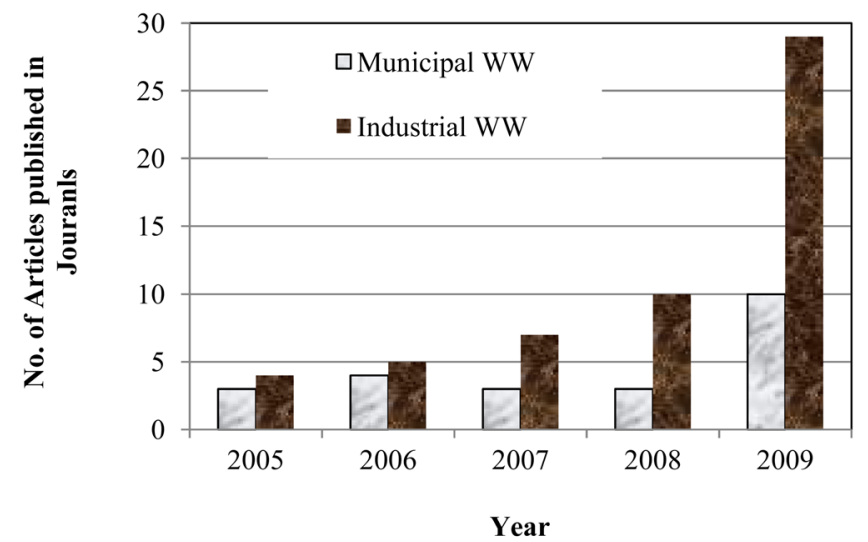

Fig. 6 Number of articles published in journals on AnMBR researches related to municipal wastewater and industrial wastewater (Scopus 2011)

potentials of AnMBR applications on low strength wastewaters with the objectives of energy recovery and water reuse are valued in the future.

At the moment, AnMBRs are not likely able to compete for applications where biofilm or granular anaerobic reactors work well, due to higher capital and operational costs. Apart from the high capital cost, operational cost and higher energy consumption of AnMBR, the process consists of operational difficulties such as membrane fouling. Anaerobic process is meant to be operated at higher biomass conditions due to reduced specific biodegradation rate ( $\mathrm{kg}$ COD $/ \mathrm{kg}$ VSS .d) as compared to aerobic process. However, operations at higher biomass levels create problems in pumping which increases membrane fouling. Membrane fouling is one of the major drawbacks in AnMBR application. Once the membrane gets fouled, permeate flux declines and frequent cleaning is essential in order get back the flux and to avoid further fouling which can deteriorate the membrane. Therefore, membrane fouling brings about high operational cost as well as replacement cost.

\section{Membrane fouling in AnMBR}

Membrane fouling in AnMBR can be reversible and/or irreversible fouling. It can take place on the membrane surface or into the pores. As soon as the membrane surface comes into contact with the biological suspension, deposition of biosolid onto membrane surface takes place. It can be removable from the membrane with appropriate physical cleaning. Therefore it is called reversible fouling. The irreversible fouling is normally caused by strong attachment of particles which is difficult of impossible to be removed by physical cleaning methods and is generally only being removed by chemical cleaning.

Membrane fouling is identified as a major hurdle to the application of AnMBRs (Kim et al. 2011). Fouling of an AnMBR system takes place mainly due to two reasons such as cake layer formation by bio-cells and the inorganic precipitation on the membrane surface (Bailey et al. 1994). Moreover, the combined deposition of these two compounds causes drastic drops in membrane permeability (Choo and Lee 1996). Further the high mixed liquor suspended solids (MLSS) concentration in the reactor, the size reduction of the biomass and the size distribution of biosolid 
particles were identified as potential causes for increased membrane fouling (Choo and Lee 1996, Bailey et al. 1994, Chang and Lee 1998). The mechanical sheer stress applied on the biomass during the pumping was identified as one of the reason causing the size reduction of bio-flocs which is then attributed to increase fouling in AnMBR. In addition, the cross flow velocity applied on biomass also affects the size reduction of biomass. Furthermore, the sludge characteristic of anaerobic thermophilic conditions are more dispersed which consequently resulted in less extracellular polymeric substances (EPS) concentration in sludge while a higher amount in bulk solution ultimately leading to sever fouling (Chang et al. 2002). The biofouling phenomena of AnMBR have not yet being widely studied. However, the recent studies on AnMBR indicate a growing attention on biofouling of AnMBRs.

In submerged AnMBRs, the cake formation was identified as a dominant feature contributing to the deterioration of membrane performance (Lin et al. 2010). Wang et al. (2010) mentioned that membrane fouling was mainly caused by the sludge cake layer formed on membrane surfaces which includes sludge particles and biopolymers such as proteins, polysaccharides and humic substances. However the contribution from sludge particles was recognized as the major biofouling over the biopolymers (Wang et al. 2010). The studies of Lin et al. (2011a, 2011b) indicates the significance of smaller flocs having higher filtration resistance over the bulk sludge due to 1.5 times higher bound EPS and significant variations of microbial community structure in smaller flocs. The authors mentioned that cake formation process started from attachment of small flocs and/or specific bacterial clusters which colonize the surface of the membrane and provide enhanced conditions that allow for cake formation to progress.

$$
\mathrm{Mg}^{2+}+\mathrm{NH}^{4+}+\mathrm{PO}_{4}{ }^{3-}+6 \mathrm{H}_{2} \mathrm{O} \rightarrow \mathrm{MgNH}_{4} \mathrm{PO}_{4} \cdot 6 \mathrm{H}_{2} \mathrm{O}
$$

The substance causing inorganic fouling was recognized as struvite $\left(\mathrm{MgNH}_{4} \mathrm{PO}_{4} \cdot 6 \mathrm{H}_{2} \mathrm{O}\right)$. Moreover, this inorganic precipitation (Eq. 1) contributes to the increased hardening of the cake layer and leads to prolonged external fouling in AnMBR (Choo and Lee 1996). In addition Kang et al. 2002 has identified the struvite precipitation inside the pores as the major factor for fouling in an inorganic membrane. Similar results were observed by $\mathrm{He}$ et al. 2005 in an inorganic membrane used for treating high concentration food wastewater under mesophilic condition. In anaerobic membranes, where ammonium as well as phosphate ions exist, struvite deposition becomes a critical issue since it could deposit together with bio-flocs and make a strong barrier.

The successful operations of AnMBRs indicates the operational fluxes of 5-20 L/m $/ \mathrm{m}^{2} \mathrm{~h}$ for longer periods of time (Wang et al. 2010, Lin et al. 2011b). However compared to aerobic MBRs (LeClech et al. 2006, Chang et al. 2002) where the operating fluxes are much higher, the AnMBR needs improvements. Hence, apart from identifying the major causes of fouling in AnMBR, studies to overcome membrane fouling need to be conducted. The study of Zhang et al. (2010) has achieved high permeate flux of $65 \mathrm{~L} / \mathrm{m}^{2} \mathrm{~h}$ with a dynamic AnMBR treating municipal wastewater. In this study, the dynamic membrane was formed by suspended solids in the settling zone and the soluble contents such as soluble microbial products and EPS. Dynamic membrane formation with suspended solids is a strategy previously studied and successfully applied in aerobic MBRs (Wu et al. 2008, Abeynayaka and Visvanathan 2011b). Biogas bubbling as a replacement of air bubbling in aerobic MBR to the membrane for minimizing membrane fouling is another application which simulates the same process in aerobic MBR. Hence, it can be seen that, even the two processes, aerobic and anaerobic, have significant differences such that some of the technologies for fouling limitations can still be applied for AnMBRs with suitable modifications. On the other hand, there 
are some significant considerations of AnMBRs which are different from the aerobic MBRs. During the startup of AnMBR the fouling was found to be higher. As mentioned in section 2, the anaerobic process which is complex and can easily be up-set, requires more time for stabilization. The study of Liao et al. (2010) indicates the operation of the reactor as a conventional reactor which allows part of the biomass to escape gives less biofouling at the startup period of the AnMBR. There are differences in fouling rates for different membrane materials, polyetherimide (PEI) and polyvinylidene fluoride (PVDF) membranes show different foulant layer properties, such as the presence of Bacteroidetes on PEI membrane but not the PVDF membrane (Gao et al. 2010). Hence, further studies to be conducted in order to find out more suitable membrane materials for AnMBRs.

\section{Conclusions}

Interest in AnMBR is increasing due to its potential for wastewater treatment applications. The combination of anaerobic process and membrane technology provides certain advantages over situations where conventional anaerobic processes are ineffective. Especially, the wastewaters with particulate matter and/or high temperature create difficulties of maintaining sustainable treatment with conventional anaerobic treatment. AnMBR is a good option for treating those types of wastewaters providing better quality effluent. For low strength wastewaters, such as municipal wastewater, the interest of AnMBR is growing in terms of energy recovery and reuse applications. Enhanced performances of anaerobic process at thermophilic conditions and the complete retention of biomass due to membrane imply the suitability of thermophilic anaerobic membrane bioreactor to treat high strength wastewaters at high temperatures. Recent research developments on AnMBR highlight membrane fouling as an important consideration. Some strategies for membrane fouling control in aerobic MBRs are applicable in AnMBRs with suitable modifications. However, the feed types, biological process and operational conditions of AnMBR which is significantly different from the aerobic process, makes further studies AnMBR necessary.

\section{References}

Abeynayaka, A. and Visvanathan, C. (2011a), "Mesophilic and thermophilic aerobic batch biodegradation, utilization of carbon and nitrogen sources in high-strength wastewater", Bioresource Technol., 102(3), 23582366.

Abeynayaka, A. and Visvanathan, C. (2011b), "Performance comparison of mesophilic and thermophilic aerobic side-stream membrane bioreactors treating high strength wastewater", Bioresource Technol., 102(9), 53455352.

Adamse, A.D. (1980), "New isolation of clostridium aceticum (wieringa). Antonie Van Leeuwenhoek", Int. J. General Molec. Microbiol., 46(6), 523-531.

Akram, A. and Stuckey, D.C. (2008a), "Flux and performance improvement in a submerged anaerobic membrane bioreactor (SAMBR) using powdered activated carbon (PAC)", Process Biochem., 43(1), 93-102.

Akram, A. and Stuckey, D.C. (2008b), "Biomass acclimatisation and adaptation during start-up of a submerged anaerobic membrane bioreactor (SAMBR)", Environ. Technol., 29(10), 1053-1065.

Anderson, G.K., Saw, C.B. and Fernandes, M.I.A.P. (1986), "Applications of porous membranes for biomass retention in biological wastewater treatment process", Process Biochem., 21(6), 174-182.

Bailey, A.D., Hansford, G.S. and Dold, P.L. (1994), "The enchancement of upflow anaerobic sludge bed reactor performance using crossflow microfiltration", Water Res., 28(2), 291-295. 
Batstone, D.J., Keller, J., Newell, R.B. and Newland, M. (2000), "Modelling anaerobic degradation of complex wastewater. I: model development", Bioresource Technol., 75(1), 67-74.

Bouallagui, H., Haouari, O., Touhami, Y., Cheikh, R.B., Marouani, L. and Hamdi, M. (2004), "Effect of temperature on the performance of an anaerobic tubular reactor treating fruit and vegetable waste", Process Biochem., 39, 2143-2148.

Borja, R., Banks, C.J. and Sinchez, E.(1996), "Anaerobic treatment of palm oil mill effluent in a two-stage upflow anaerobic sludge blanket (UASB) system", J. Biotechnol., 45(2), I25-135.

Borja, R., Martiqb, A., Banks, C.J., Alonsob, V. and Chicab, A. (1995), “ A kinetic study of anaerobic digestion of olive mill wastewater at mesophilic and thermophilic Temperatures", Environ. Pollution, 88(1), 13-18.

Bravo, A.D., Filippi, G.R. and Chamy, R. (2009), "Anaerobic treatment of low strength wastewater with a high fraction of particulate matter in an unconventional two phase ASBRs system", Biochem. Eng. J., 43(3), 297302.

Brockmann, M. and Seyfried, C.F. (1996), "Sludge activity and cross flow microfiltration-a non beneficial relationship", Water Sci. Technol., 34(9), 205 - 213.

Calderón, K., Rodelas, B., Cabirol, N., González-López, J. and Noyola, A. (2011), "Analysis of microbial communities developed on the fouling layers of a membrane-coupled anaerobic bioreactor applied to wastewater treatment", Bioresource Technol., 102(7), 4618-4627.

Chang, I.S. and Lee, C.H. (1998), "Membrane filtration characteristics in membrane-coupled activated sludge system - the effect of physiological states of activated sludge on membrane fouling", Desalination, 120(3), 221-233.

Chang, I.S., Clech, P.L., Jefferson, B. and Judd, S. (2002), "Membrane fouling in membrane bioreactors for wastewater treatment", J. Environ. Eng., 128(11), 1018-1029.

Chen, Y., Cheng, J.J. and Creamer, K.S. (2008), "Inhibition of anaerobic digestion process: A review", Bioresource Technol., 99(10), 4044-4064.

Cheong, D. and Hansen, C.L. (2008), "Effect of feeding strategy on the stability of anaerobic sequencing batch reactor responses to organic loading conditions", Bioresource Technol., 99(11), 5058-5068.

Choo, K.H. and Lee, C.H. (1996), "Membrane fouling mechanisms in the membrane-coupled anaerobic bioreactor", Water Res., 30(8), 1771- 1780.

de Gioannis, G., Diaz, L.F., Muntoni, A. and Pisanu, A. (2008), "Two- phase anaerobic digestion within a solid waste/wastewater integrated management system", Waste Management, 28(10), 1801-1808.

Fakhru'l-Razi, A. (1994), “Ultrafiltration membrane separation for anaerobic wastewater treatment”, Water Sci. Technol., 30(12), 321-327.

Fang, H.H.P., Chui, H.K., Li, Y.Y. and Chen, T. (1994a), "Microbial structure and activity of UASB granules treating different wastewaters", Water Sci. Technol., 30(12), 87-96.

Fang, H.H.P., Chui, H.K., Li, Y.Y. and Chen, T.(1994b), "Performance and granule characteristics of UASB process treating wastewater with hydrolyzed proteins", Water Sci. Technol., 30(8), 55-63.

Ganesh, R., Rajinikanth, R., Thanikal, J.V., Ramanujam, R.A. and Torrijos, M. (2010), "Anaerobic treatment of winery wastewater in fixed bed reactor", Bioprocess Biosystem Eng., 33, 619-628.

Gao, D., Zhang, T., Tang, C.Y.Y., Wu, W., Wong, C., Lee, Y.H., et al. (2010), "Membrane fouling in an anaerobic membrane bioreactor: Differences in relative abundance of bacterial species in the membrane foulant layer and in suspension", $J$. Membrane Sci., 364(1-2), 331-338.

Ghaniyari-Benis, S., Borja, R., Monemian, A.S. and Goodarzi, V. (2009), "Anaerobic Treatment of Synthetic medium strength wastewater using a multistage biofilm reactor", Bioresource Technol., 100, 1740-1745.

Harada, H., Momonoi, K., Yamazaki, S. and Takizawa, S. (1994), "Application of anaerobic UF membrane reactor for treatment of a wastewater containing high strength particulate organics", Water Res., 30(12), 307-319.

He, Y., Xu, P., Li, C. and Zhang, B. (2005), "High concentration food wastewater treatment by an anaerobic membrane bioreactor", Water Res., 39(17), 4110-4118.

Henze, M. and Harremoes, P. (1983), "Anaerobic treatment of wastewater in fixed film reactors - a literature review”, Water Sci. Technol., 15(8-9), 1-101.

Ho, J. and Sung, S.(2009), "Anaerobic membrane bioreactor treatment of synthetic municipal wastewater at ambient temperature", Water Environ. Res., 81(9), 922-928.

Huang, Z., Ong, S.L. and Ng, H.Y. (2011), "Submerged anaerobic membrane bioreactor for low-strength 
wastewater treatment: Effect of HRT and SRT on treatment performance and membrane fouling", Water Res., 45(2), 705-713.

Jeison, D. and van Lier, J.B. (2007), "Feasibility of thermophilic anaerobic submerged membrane bioreactors (AnSMBR) for wastewater treatment", Desalination, 231(1-3), 227-235.

Jeison, D. and van Lier, J.B. (2006), "Cake layer formation in anaerobic submerged membrane bioreactor (AnSMBR) for wastewater treatment", J. Membrane Sci., 284(1-2), 227- 236.

Jeison, D. and van Lier, J.B. (2008), "Anaerobic wastewater treatment and membrane filtration: a one night strand or a sustainable development", Water Sci. Technol., 57(2), 527 -532.

Jeison, D., Diaz, I. and van Lier, J.B. (2008), "Anaerobic membrane bioreactors: are membranes really necessary", Electronic J. Biotechnol., 11(4).

Jeison, D., Plugge, C.M., Pereira, A. and Lier, J.B.V. (2009a), "Effects of the acidogenic biomass on the performance of an anaerobic membrane bioreactor for wastewater treatment", Bioresource Technol., 100(6), 1951-1956.

Jeison, D., Kremer, B. and van Lier, J.B. (2009b), "Application of membrane enhanced biomass retention to the anaerobic treatment of acidified wastewater under extreme saline condition", Sep. Purif. Technol., 64(2), 198-205.

Judd, S. (2008), The status of membrane bioreactor technology. Trends in Biotechnology, 26(2), 109-116.

Kang, J.I., Yoon, S.H. and Lee, C.H. (2002), "Comparison of the filtration characteristics of organic and inorganic membranes in a membrane-coupled anaerobic bioreactor", Water Res., 36(7), 1803-1813.

Kayhanian, M. (1994), "Performance of a high-solids anaerobic digestion process under various ammonia concentrations", J. Chem. Technol. Biotechnol., 59(4), 349-352.

Khanal, S.K. (2008), "Anaerobic biotechnology for bioenergy production : principles and applications. Jhon Willey \& Sons, USA. ISBN: 978-0-8138-2346-1.

Kim, J., Kim, K., Ye, H., Lee, E., Shin, C., McCarty, P. L., et al. (2011), “Anaerobic fluidized bed membrane bioreactor for wastewater treatment", Environ. Sci. Technol., 45(2), 576-581.

Le-Clech, P., Chen, V. and Fane, T.A.G. (2006), "Fouling in membrane bioreactors used in wastewater treatment", J. Membrane Sci., 284(1-2), 17-53.

Lee, S.M., Jung, J.Y. and Chung, Y.C. (2001), "Noval method for enchnaning permeate flux of submerged membrane system in two phase anaerobic reactor", Water Res., 35(2), 471-477.

Lew, B., Tarre, S., Beliavski, M., Dosoretz, C. and Green, M. (2009), "Anaerobic membrane bioreactor (AnMBR) for domestic wastewater treatment", Desalination, 243(1-3), 251-257.

Liao, B.Q., Xie, K., Lin, H.J. and Bertoldo, D. (2010), "Treatment of kraft evaporator condensate using a thermophilic submerged anaerobic membrane bioreactor", Water Sci. Technol., 61(9), 2177-2183.

Liao, B., Kraemer, J.T. and Bagley, M.D. (2006), "Anaerobic membrane bioreactors: application and research directions", Crit. Rev. Environ. Sci. Technol., 36, 489-530.

Lin, H.J., Gao, W.J., Leung, K.T., Liao, B.Q. and Lin, H.J. (2011a), "Characteristics of different fractions of microbial flocs and their role in membrane fouling", Water Sci. Technol., 63(2), 262-269.

Lin, H., Liao, B. -., Chen, J., Gao, W., Wang, L., Wang, F., et al. (2011b), "New insights into membrane fouling in a submerged anaerobic membrane bioreactor based on characterization of cake sludge and bulk sludge", Bioresource Technol., 102(3), 2373-2379.

Lin, H.J., Xie, K., Mahendran, B., Bagley, D.M., Leung, K.T., Liss, S.N., et al. (2010), "Factors affecting sludge cake formation in a submerged anaerobic membrane bioreactor", J. Membrane Sci., 361(1-2), 126-134.

McCarty, P.L. and Smith, D.P. (1986), “Anaerobic wastewater treatment”, Environ. Sci. Technol., 20, 1200-1226.

Melin, T., Jefferson, B., Bixio, D., Thoeye, C., De Wilde, W., De Koning, J., et al. (2006), "Membrane bioreactor technology for wastewater treatment and reuse", Desalination, 187(1-3), 271-282.

Najafpour, G.D., Zinatizadeh, A.A.L., Mohamed, A.R., Hasnain Isa, M. and Nasrollahzadeh, H. (2006), "Highrate anaerobic digestion of palm oil mill effluent in an upflow anaerobic sludge-fixed film bioreactor", Process Biochem., 41(2), 370-379.

Parawira, W., Murto, M., Read, J.S. and Mattiasson, B. (2007), “A Study of Two-Stage Anaerobic Digestion of Solid Potato Waste using Reactors under Mesophilic and Thermophilic Conditions", Environ. Technol., 28(11), 1205-1216.

Pavlostathis, S.G. and Giraldo-Gomez, E. (1991), "Kinetics of anaerobic treatment: A critical review", Crit. Rev. Environ. Contr., 21 (5-6), 411-490. 
Saddoud, A., Hassairi, I. and Sayadi, S. (2007), "Anaerobic membrane reactor with pahse separation for the treatment of cheese whey", Bioresource Technol., 98(11), 2102- 2108.

Scopus (2011). Scopus key-word searches and abstracts. Retrieved from: www.scopus.com February 2011.

Shizas, I. and Bagley, D.M. (2004), "Experimental determination of energy content of unknown organics in municipal wastewater streams", J. Energy Eng., 130(45).

Speece, R.E., Boonyakitsombut, S., Kim, M., Azbar, N. and Ursillo, P. (2006), "Overview of anaerobic treatment: thermophilic and propionate implications", Water Environ. Res., 78(5), 460- 473.

Stuckey, D.C. and Trzcinski, A.P. (2009), "Continuous treatment of the organic fraction of municipal solid waste in an anaerobic two stage membrane process with liquid recycle", Water Res., 43(9), 2449-2462.

Sutton, P.M., Melcer, H., Schraa, O.J. and Togna, A.P. (2011), "Treating municipal wastewater with the goal of resource recovery", Water Sci. Technol., 63(1), 25-31.

Teoh, M.M.,Wang, K.Y., Bonyadi, S., Yang, Q. and Chung, T. (2011), "Emerging membrane technologies developed in NUS for water reuse and desalination applications: membrane distillation and forward osmosis", Membrane Water Treatment, 2(1), 2011

UNFCCC (2009). Copenhagen Accord. Retrieved from: www.unfccc.int March 2010.

van Lier, J.B. (1996), "Limitations of thermophilic anaerobic wastewater treatment and the concequences for process design", Antonie van Leeuwenhoek, 69(1), 1-14.

Vallero, M.V.G., Lettinga, G. and Lens, P.N.L. (2005), "High rate sulfate reduction in a submerged anaerobic membrane bioreactor (SAMBaR) at high salinity", J. Membrane Sci., 253(1-2), 217-232.

Visvanathan, C., Ben Aim, R. and Parameshwaran, K. (2000), "Membrane separation bioreactors for wastewater treatment", Crit. Rev. Environ. Sci. Technol., 30(1), 1-48.

Wang, Z., Ye, S., Wu, Z. and Tang, S. (2010), Application of anaerobic membrane bioreactor to the treatment of low-strength municipal wastewater. Paper presented at the 2010 4th International Conference on Bioinformatics and Biomedical Engineering, iCBBE 2010. Article number 5518308.

Weigel, P.H. and Oka, J.A. (1981), "Temperature dependence of endocytosis mediated by the asialoglycoprotein receptor in isolated rat hepatocytes. evidence for two potentially rate-limiting steps", J. Biological Chem., 256(6), 2615-2617.

Wijekoon, K.C., Visvanathan, C. and Abeynayaka, A. (2011), "Effect of organic loading rate on VFA production, organic matter removal and microbial activity of a two-stage thermophilic anaerobic membrane bioreactor", Bioresource Technol., 102(9), 5353-5360.

Wu, J., Le-Clech, P., Stuetz, R.M., Fane, A.G. and Chen, V. (2008). "Novel filtration mode for fouling limitation in membrane bioreactors", Water Res., 42(14), 3677-3684.

WPCF, Water pollution control federation (1987), Manual of practice 16, Anaerobic sludge digestion, $2^{\text {nd }}$ edition. Water Pollution Control Federation, Aexandra, VA, USA.

Yejian, Z., Li, Y., Xiangli, Q., Lina, C., Xiangjun, N., Zhijian, M. and Zhenjia, Z. (2008), "Integration of biological method and membrane technology in treating palm oil mill effluent" J. Environ. Sci., 20(5), 558564.

Yeoh, B.G. (1997), "Two-phase anaerobic treatment of cane-molasses alcohol stillage", Water Sci. Technol., 36(6), 441-448.

Yilmaz, T., Yuceer, A. and Basibuyuk, M. (2008), "A comparison of the performance of mesophilic and thermophilic anaerobic filters treating papermill wastewater", Bioresource Technol., 99(1), 156-163.

Zhang, X., Wang, Z., Wu, Z., Lu, F., Tong, J. and Zang, L. (2010), "Formation of dynamic membrane in an anaerobic membrane bioreactor for municipal wastewater treatment", Chem. Eng. J., 165(1), 175-183.

Zinatizadeh, A.A.L., Mohamed, A.R., Najafpour, G.D., Isa, M.H. and Nasrollahzadeh, H. (2006), "Kinetic evaluation of palm oil mill effluent digestion in a high rate up-flow anaerobic sludge fixed film bioreactor", Process Biochem., 41(5), 1038-1046.

$C C$ 


\section{List of abbreviations}

$\begin{array}{ll}\text { AFBR } & =\text { anaerobic fluidized-bed reactor } \\ \text { AnMBR } & =\text { anaerobic membrane bioreactor } \\ \text { ASBR } & =\text { anaerobic sequencing batch reactor } \\ \text { BOD }_{5} & =\text { five day biochemical oxygen demand } \\ \text { COD }_{\text {In }} & =\text { influent chemical oxygen demand } \\ \text { COD }_{\text {R }} & =\text { removed chemical oxygen demand } \\ \text { CSTR } & =\text { continuous stirring tank reactor } \\ \text { EPS } & =\text { extracellular polymeric substances } \\ \text { GHG } & =\text { green house gases } \\ \text { MBR } & =\text { membrane bioreactor } \\ \text { MLSS } & =\text { mixed liquor suspended solids, } \\ \text { MLVSS } & =\text { mixed liquor volatile suspended solids } \\ \text { OLR } & =\text { organic loading rate } \\ \text { PAC } & =\text { powdered activated carbon } \\ \text { SRT } & =\text { solid retention time } \\ \text { UAFP } & =\text { upflow anaerobic filter process } \\ \text { UASB } & =\text { upflow anaerobic sludge blanket } \\ \text { VFA } & =\text { volatile fatty acids } \\ \text { WPCF } & =\text { water pollution control federation }\end{array}$

